\title{
Tomography of Biological Materials using Focused Ion Beam Sectioning and Backscattered Electron Imaging
}

D. A. Matthijs de Winter ${ }^{a}$, Chris T. W. M. Schneijdenberg ${ }^{a}$, Misjaël N. Lebbink ${ }^{a}$, Liesbeth Hekking ${ }^{a}$, Jan Andries Post ${ }^{a}$, Ben Lich ${ }^{c}$, Arie J. Verkleij ${ }^{a}$, Martyn R. Drury ${ }^{b}$, Bruno M. Humbel ${ }^{\mathrm{a}}$

${ }^{a}$ Electron Microscopy and Structure Analysis, Cellular Architecture and Dynamics, Faculty of Sciences, Utrecht University, NL-3584 CH Utrecht, The Netherlands. ${ }^{b}$ Earth Sciences, Faculty of Geosciences, Utrecht University, NL-3584 CD Utrecht, The Netherlands.

${ }^{\mathrm{c}}$ FEI Company, Achtseweg Noord 5, $5600 \mathrm{KA}$ Eindhoven, The Netherlands

Tomography in a focused ion beam (FIB) scanning electron microscope (SEM) is a powerful method for the characterization of three-dimensional micro- and nanostructures. It has been widely applied in studying three-dimensional nano- and microstructures of materials such as metals and semi-conductors (e.g., Inkson et al., 2001; McGrouther and Munroe, 2007). In biology the method is extremely useful to study cell / implant interactions (Giannuzzi et al., 2007; Greve et al., 2007; Nalla et al., 2005). The density difference between the biological matter and the implant is so extreme that standard microtomy is very difficult if not impossible. An other application is to dig into biological objects and reveal the structures of interest (Drobne et al., 2007; Drobne et al., 2005a; Drobne et al., 2005b). The real power of FIB-SEM tomography, however, is to find the place of interest at low magnification in the SEM and then analyse the spot at higher magnification with the Slice and View ${ }^{\mathrm{TM}}$ (FEI Company) method, which means cutting a slice off with the ion beam and imaging the fresh surface with the electron beam, usually with the backscatter electron mode (De Winter et al., 2009; Heymann et al., 2006; Knott et al., 2008). More advanced investigations aim at using the focused ion beam scanning microscope as an ultramicrotome to create thick cryo-sections (Marko et al., 2006; Marko et al., 2007). In this presentation we will share our experience in analysing endothelial cells and atherosclerotic plaques of Epon embedded samples with FIBSEM tomography.

De Winter, D.A.M., C.T.W.M. Schneijdenberg, M.N. Lebbink, B. Lich, A.J. Verkleij, M.R. Drury, and B.M. Humbel, 2009. Tomography of insulating biological and geological materials using focused ion beam (FIB) sectioning and low kV BSE imaging. Journal of Microscopy: in press.

Drobne, D., M. Milani, V. Lešer, and F. Tatti, 2007. Surface damage induced by FIB milling and imaging of biological samples is controllable. Microscopy Research and Technique.

Drobne, D., M. Milani, A. Zrimec, V. Lešer, and M. Berden Zrimec, 2005a. Electron and ion imaging of gland cells using the FIB/SEM system. Journal of Microscopy 219: 29-35.

Drobne, D., M. Milani, A. Zrimec, M.B. Zrimec, F. Tatti, and K. Draslar, 2005b. Focused ion beam/scanning electron microscopy studies of Porcellio scaber (Isopoda, Crustacea) digestive gland epithelium cells. Scanning 27: 30-34.

Giannuzzi, L.A., D. Phifer, N.J. Giannuzzi, and M.J. Capuano, 2007. Twodimensional and 3-dimensional analysis of bone/dental implant linterfaces 
with the use of focused ion beam and electron microscopy. Journal of Oral and Maxillofacial Surgery 65: 737-747.

Greve, F., S. Frerker, A.G. Bittermann, C. Burkhardt, A. Hierlemann, and H. Hall, 2007. Molecular design and characterization of the neuro-microelectrode array interface. Biomaterials 28: 5246-5258.

Heymann, J.A.W., M. Hayles, I. Gestmann, L.A. Giannuzzi, B. Lich, and S. Subramaniam, 2006. Site-specific 3D imaging of cells and tissues with a dual beam microscope. Journal of Structural Biology 155: 63-73.

Inkson, B.J., M. Mulvihill, and G. Möbus, 2001. 3D determination of grain shape in a FeAl-based nanocomposite by 3D FIB tomography. Scripta Materialia 45: 753-758.

Knott, G., H. Marchman, D. Wall, and B. Lich, 2008. Serial section scanning electron microscopy of adult brain tissue using focused ion beam milling. Journal of Neuroscience 28: 2959 -2964.

Marko, M., C.E. Hsieh, W. Moberlychan, C.A. Mannella, and J. Frank, 2006. Focused ion beam milling of vitreous water: prospects for an alternative to cryo-ultramicrotomy of frozen-hydrated biological samples. Journal of Microscopy 222: 42-47.

Marko, M., C. Hsieh, R. Schalek, J. Frank, and C.A. Mannella, 2007. Focused-ionbeam thinning of frozen hydrated biological specimens for cryoelectron microscopy. Nature Methods 4: 215-217.

McGrouther, D., and P.R. Munroe, 2007. Imaging and analysis of 3-D structure using a dual beam FIB. Microscopy Research and Technique 70: 186-194.

Nalla, R.K., A.E. Porter, C. Daraio, A.M. Minor, V. Radmilovic, E.A. Stach, A.P. Tomsia, and R.O. Ritchie, 2005. Ultrastructural examination of dentin using focused ion-beam cross-sectioning and transmission electron microscopy. Micron 36: 672-680. 